\title{
Pengaruh Kepemimpinan Transformasional dan Motivasi terhadap Kinerja Karyawan Credit Union (CU) Betang Asi Palangka Raya
}

\author{
Iram Siti Aisyah ${ }^{1)}$ \\ T. M Murniati ${ }^{2}$ \\ Ina Karuehni $^{3}$ \\ Fakultas Ekonomi dan Bisnis \\ Universitas Palangka Raya, Indonesia \\ Email: aisyah.irram@gmail.com
}

\begin{abstract}
Abstrak
Tujuan - Penelitian ini bertujuan untuk mengetahui pengaruh kepemimpinan transformasi dan motivasi terhadap kinerja karyawan baik secara parsial maupun simultan pada Credit Union (CU) Betang Asi Palangka Raya.

Desain/Metodelogi/Pendekatan - Penelitian ini meggunakan metode kuantitatif, dengan teknik sampel adalah jenuh, dimana responden berjumlah 30 orang. Data yang dikumpulkan dengan kuesioner dan kemudian dianalisis dengan alat analisis Regresi Linier Berganda. Software yang digunakan dalam penelitian ini adalah SPSS versi 24.

Temuan Penelitian - Hasil analisis diketahui bahwa kepemimpinan transformasional dan motivasi berpengaruh positif dan signifikan baik secara parsial dan simultan.

Kata kunci: kepemimpinan transformasional;motivasi;kinerja karyawan

\section{The effect of transformational leadership and motivation on employee performance Credit Union (CU) Betang Asi Palangka Raya}

\begin{abstract}
Purpose - This study aims to determine the effect of transformational leadership and motivation on employee performance both partially and simultaneously at the Betang Asi Palangka Raya Credit Union (CU).

Design / Methodology / Approach - This study uses quantitative methods, with the sampling technique is saturated, where the respondents are 30 people. The data were collected by means of a questionnaire and then analyzed by means of multiple linear regression analysis. The software used in this study is SPSS version 24.

Research Findings - The results of the analysis show that transformational leadership and motivation have a positive and significant effect both partially and simultaneously.
\end{abstract}

Keywords: transformational leadership; motivation; employee performance

Pedro Liberato, Elisa Alen and Dalia Liberato. Published in the Jurnal Manajemen sains dan Organsasi. Published by FEB UPR Publishing Limited. This article is published under the Creative Commons Attribution (CC BY 4.0) licence. Anyone may reproduce, distribute, translate and create derivative works of this article (for both commercial and non-commercial purposes), subject to full attribution to the original publication and authors. 


\section{PENDAHULUAN}

Perkembangan perekonomian saat ini semakin dinamis, banyak dari sektor ekonomi telah banyak menyumbangkan kontribusi sebuah lembaga keuangan. Semakin maraknya pertumbuhan transaksi keuangan, maka semakin beragam jenis jasa keuangan yang muncul guna melakukan transaksi bagi kebutuhan masyarakat seperti Koperasi kredit/Credit Union (CU). Koperasi kredit/Credit Union adalah koperasi yang melakukan usaha penyimpanan dan peminjaman sejumlah uang untuk keperluan para anggotanya dengan biaya murah (Kasmir, 2014). Dalam pencapaian visi dan misi sebuah lembaga perusahaan atau koperasi membutuhkan pengelolaan manajerial yang baik. Oleh karena itu, perusahaan atau koperasi harus memiliki karyawan yang berpengetahuan dan berketerampilan tinggi serta usaha untuk mengelola perusahaan atau koperasi seoptimal mungkin sehingga kinerja karyawan meningkat.

Dalam pengelolaan sumber daya manusia terdapat kepemimpinan, yang menjadi tonggak awal sebuah organisasi atau koperasi akan dibawa kearah mana. Faktor kepemimpinan dapat menjadi masalah bagi karyawan yang akan berdampak pada kinerjanya. Salah satu pendekatan terbaru dan paling popular untuk kepemimpinan yang telah menjadi fokus banyak penelitian sejak awal tahun 1980-an, adalah pendekatan transformasional. Bass dan Riggio dalam Nourthouse (2013) menyatakan bahwa popularitas kepemimpinan transformasional, yang memenuhi kebutuhan kelompok kerja dimasa sekarang, yang ingin diinspirasi dan diberdayakan agar berhasil dimasa-masa yang tidak pasti. Karyawan merasa percaya, kagum, loyal dan hormat terhadap atasannya sehingga bawahan termotivasi untuk berbuat lebih banyak dari pada apa yang biasa dilakukan dan diharapkannya. Seperti yang pernah di ulas oleh Sedarmayanti (2010) bahwa kepemimpinan transformasional lebih meningkatkan motivasi dan kinerja dan pengikutnya, sehingga erat kaitannya dengan motivasi sebagai peningkatan kinerja. Tania (2017) dalam penelitiannya menemukan bahwa kepemimpinan transformasional berpengaruh positif dan signifikan yang berarti semakin tinggi kepemimpinan transformasional maka semakin tinggi kinerja karyawan.

Faktor lain yang mempengaruhi kinerja selain kepemimpinan adalah motivasi. Motivasi sangat penting dimiliki oleh pimpinan dan karyawan dalam meningkatkan semangat kerja dan kinerja para karyawan. Pemberian motivasi kerja oleh seorang pemimpin merupakan tindakan positif yang dapat menimbulkan dorongan atau semangat kerja bagi karyawannya dalam mencapai tujuan dari organisasi/perusahaan tersebut. Motivasi juga akan mendorong seseorang untuk bekerja lebih baik agar meraih kinerja yang diharapkan, sehingga mendapatkan apa yang menjadi kebutuhannya. Nurhadian (2017) dalam penelitiannya menemukan bahwa motivasi berpengaruh positif dan signifikan terhadap kinerja karyawan yang berarti semakin tinggi motivasi yang dimiliki karyawan maka semakin kinerja karyawan.

Credit Union (CU) Betang Asi adalah lembaga pemberdayaan anggota melalui pelayanan keuangan yang profesional untuk meningkatkan kesejahteraan anggota. CU Betang Asi berdiri pada tanggal 26 Maret 2003 di Palangka Raya, Kalimantan Tengah. Credit union (CU) Betang Asi Palangka

Raya selalu berupaya meningkatkan terciptanya sumber daya yang berkualitas professional. Credit union (CU) Betang Asi Palangka Raya selalu senantiasa membina hubungan baik dan harmonis dengan karyawannya dengan pengarahan motivasi dengan 
menciptakan gaya kepemimpinan yang baik sehingga para karyawan merasa terpacu untuk bekerja lebih keras agar kinerja yang dicapai juga tinggi. Seperti halnya Credit union (CU) Betang Asi Palangka Raya memberikan penghargaan yang layak kepada karyawan yang berprestasi, meningkatkan kompetensi karyawan melalui pengembangan dan peningkatan keahlian serta kemampuan individual karyawan, memberikan jaminan perlindungan hukum kepada karyawan dalam kaitannya dalam tugas-tugas pada Credit union (CU) Betang Asi Palangka Raya, memberikan jaminan kesehatan bagi karyawan dan keluarga, memberikan imbalan jasa yang layak dan jaminan pensiun, memberikan kepastian sistem mutasi karyawan demi terciptanya kenyamanan dan keharmonisan kerja serta menghormati hak dan kewajiban karyawan berdasarkan peraturan perundang-undangan dan norma perusahaan serta kesepakatan dalam Perjanjian Kerja Bersama

Berdasarkan latar belakang yang ada di atas, maka tujuan dari penelitian ini adalah untuk mengetahui dan menganalisa pengaruh kepemimpinan transformasional dan motivasi terhadap kinerja karyawan baik secara parsial maupun simultan pada Credit union (CU) Betang Asi Palangka Raya.

\section{Gambar 1. Kerangka Berpikir}

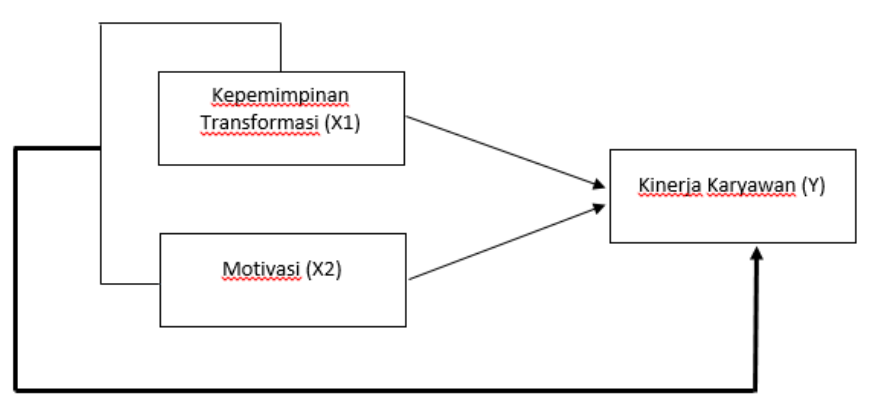

Berdasarkan kerangka berpikir diatas, maka penulis mengajukan hipotesis sebagai

berikut :

H1 : Kepemimpinan transformasional berpengaruh secara parsial terhadap kinerja karyawan.

H2 : Motivasi berpengaruh secara parsial terhadap kinerja karyawan.

H3 : Kepemimpinan transformasional dan motivasi berpengaruh secara simultan terhadap kinerja karyawan.

\section{Metode Penelitian}

Penelitian ini menggunakan pendekatan kuantitatif. Penelitian ini berlokasi di Credit Union (CU) Betang Asi Palangka Raya. Sumber data diperoleh dari penyebaran kuesioner dan wawancara. Responden dalam penelitian ini berjumlah 30 orang karyawan Credit Union (CU) Betang Asi Palangka Raya.

Penelitian ini menggunakan data primer melalui penyebaran kuesioner dan wawancara dan data sekunder yang bersumber dari Credit Union (CU) Betang Asi Palangka Raya berupa data jumlah karyawan, lokasi, sejarah koperasi dan struktur organisasi.

Teknik pengambilan sampel yang digunakan yaitu sampel jenuh atau sensus. Penelitian ini menggunakan alat analisis Regresi Linier Berganda dan diolah menggunakan aplikasi 
SPSS versi 24.

Variabel dan indikator yang digunakan dalam penelitian ini dapat dilihat dalam tabel berikut ini :

Tabel 1. Identifikasi variabel

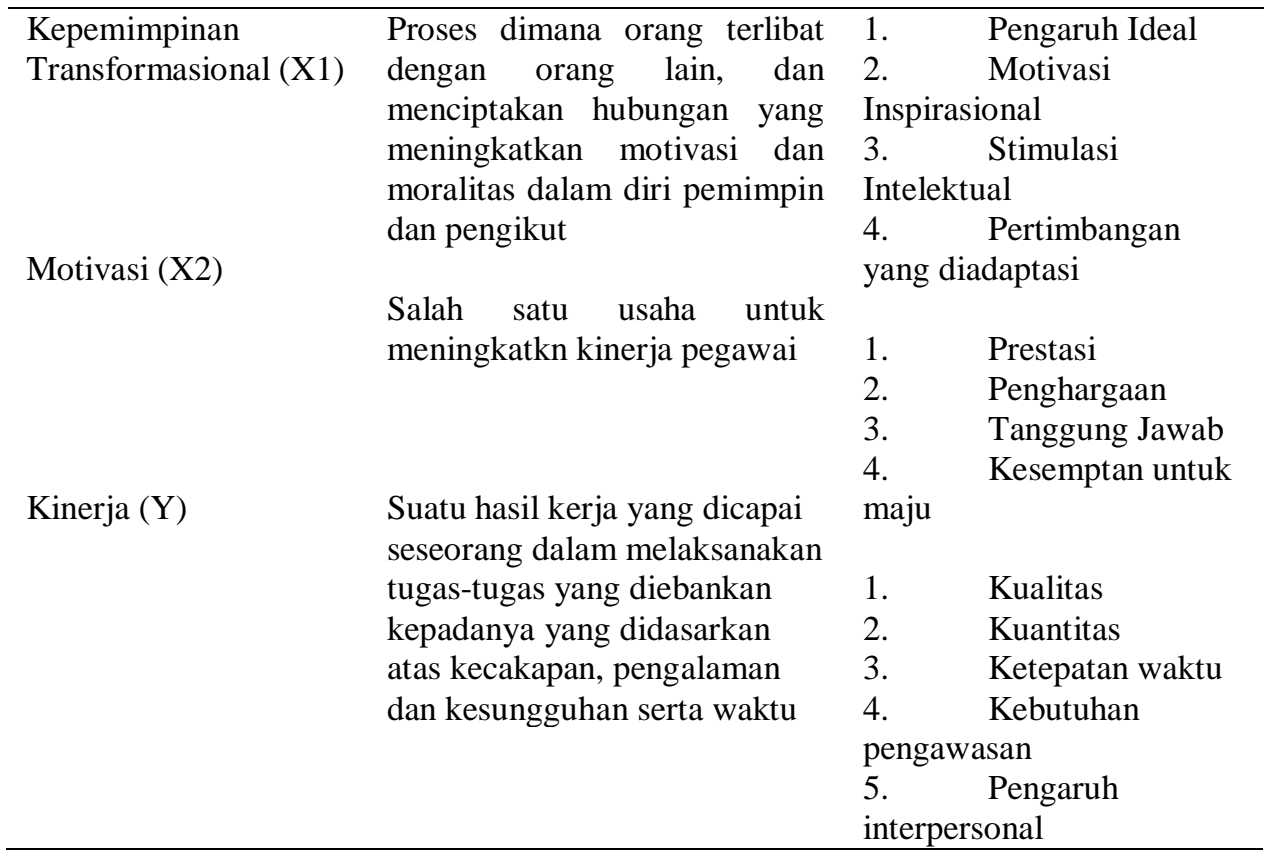

Sumber: Konsep yang dikembangkan dalam penelitian ini, 2019

\section{HASIL DAN PEMBAHASAN}

Setelah pengumpulan data dengan menggunakan kuesioner yang disebarkan kepada responden yakni Karyawan Credit Union (CU) Betang Asi palangka Raya berjumlah 30 orang. Informasi tentang karakterisistik responden dapat dilihat pada Tabel 2. berikut ini:

Tabel 2. Karakteristik Responden

\begin{tabular}{lcc}
\hline \multicolumn{1}{c}{ Uraian } & Frekuensi & Presentase \\
\hline Jenis Kelamin: & 16 & 53,3 \\
Laki-laki & 14 & 46,7 \\
Perempuan & 30 & \\
\hline Total & & \\
\hline Usia: & 17 & 56,7 \\
$21-35$ & 12 & 40 \\
$36-50$ & 1 & 3,3 \\
$51-60$ & 30 & \\
\hline Total & 6 & 20 \\
\hline Lama Bekerja: & 16 & 53,3 \\
$<5$ tahun & 6 & 20 \\
$6-10$ tahun & 2 & \\
$11-15$ tahun & & \\
$>15$ tahun & 30 & \\
\hline Total & &
\end{tabular}


Uji Validitas

Uji validitas digunakan untuk mengukur sah atau valid tidaknya suatu kuesioner. Suatu kuesioner dikatakan valid jika pertanyaan pada kuesioner mampu untuk mengungkapkan sesuatu yang akan diukur oleh kuesioner tersebut (Ghozali, 2011).

Tabel 3. Hasil Uji Validitas

\begin{tabular}{cccc}
\hline Item Pernyatan & r hitung & r table & Keterangan \\
\hline X1.1 & 0,711 & 0,3610 & Valid \\
X1.2 & 0,646 & 0,3610 & Valid \\
X1.3 & 0,706 & 0,3610 & Valid \\
X1.4 & 0,781 & 0,3610 & Valid \\
X1.5 & 0,798 & 0,3610 & Valid \\
X1.6 & 0,798 & 0,3610 & Valid \\
X2.1 & 0,845 & 0,3610 & Valid \\
X2.2 & 0,725 & 0,3610 & Valid \\
X2.3 & 0,854 & 0,3610 & Valid \\
X2.4 & 0,854 & 0,3610 & Valid \\
X2.5 & 0,874 & 0,3610 & Valid \\
X2.6 & 0,843 & 0,3610 & Valid \\
X2.7 & 0,529 & 0,3610 & Valid \\
X2.8 & 0,506 & 0,3610 & Valid \\
X2.9 & 0,822 & 0,3610 & Valid \\
X2.10 & 0,824 & 0,3610 & Valid \\
Y1.1 & 0,914 & 0,3610 & Valid \\
Y1.2 & 0,886 & 0,3610 & Valid \\
Y1.3 & 0,914 & 0,3610 & Valid \\
Y1.4 & 0,712 & 0,3610 & Valid \\
Y1.5 & 0,934 & 0,3610 & Valid \\
Y1.6 & 0,934 & 0,3610 & Valid \\
Y1.7 & 0,928 & 0,3610 & Valid \\
Y1.8 & 0,928 & 0,3610 & Valid \\
\hline
\end{tabular}

Hasil pengujian validitas item pernyataan dari semua variabel bebas maupun terikat menunjukan nilai signifikan lebih kecil dari 0,05 sehingga dinyatakan semua variabel penelitian baik bebas maupun terikat telah valid.

Uji Reliabilitas

Uji reliabilitas digunakan untuk mengetahui konsistensi alat ukur, apakah alat pengukur yang digunakan dapat diandalkan dan tetap konsisten jika pengukuran tersebut diulang. Penelitian ini menggunakan metode Cronbach's Alpha.

Tabel 4. Hasil Uji Reliabilitas

\begin{tabular}{lcc}
\hline \multicolumn{1}{c}{ Variabel } & Cronbach's Alpha & Kesimpulan \\
\hline Kepemimpinan transformasional(X1) & 0,832 & Reliabel \\
Motivasi (X2) & 0,925 & Reliabel \\
Kinerja (Y) & 0,964 & Reliabel \\
\hline Sun
\end{tabular}

Sumber: Data primer diolah, 2019

Hasil pengujian reliabilitas item pernyataan dari semua variabel menunjukan nilai Cronbach's Alpha lebih besar dari 0,7. Oleh karena itu semua iem pernyataan variabel dinyatakan reliabel. 
Analisis Regresi Linier Berganda

Analisis regresi linier berganda merupakan analisis statistik yang menghubungkan antara dua atau lebih variabel independen dengan variabel dependen (Lupiyoadi dan Ikhsan, 2015). Analisis ini bertujuan untuk mengetahui pengaruh antara variabel independen dalam mempengaruhi variabel dependen baik secara simultan maupun parsial.

Tabel 5. Hasil Analisis Regresi Linier Berganda

\begin{tabular}{|c|c|c|c|c|c|c|c|}
\hline \multicolumn{8}{|c|}{ Coefficients $^{\mathrm{a}}$} \\
\hline \multirow[b]{3}{*}{ Model } & \multirow{2}{*}{\multicolumn{2}{|c|}{$\begin{array}{l}\text { Unstandardized } \\
\text { Coefficients } \\
\text { Std }\end{array}$}} & \multirow{2}{*}{\multicolumn{2}{|c|}{$\begin{array}{l}\text { Standardized } \\
\text { Coefficients }\end{array}$}} & \multicolumn{3}{|c|}{$\begin{array}{c}\text { Collinearity } \\
\text { Statistics }\end{array}$} \\
\hline & & & & & & & \\
\hline & B & Error & Beta & $\mathbf{t}$ & Sig. & Tolerance & VIF \\
\hline 1 (Constant) & -29.018 & 11.260 & & -2.577 & .016 & & \\
\hline $\mathrm{X} 1$ & 1.110 & .396 & .395 & 2.805 & .009 & .890 & 1.124 \\
\hline $\mathrm{X} 2$ & .777 & .223 & .490 & 3.483 & .002 & .890 & 1.124 \\
\hline
\end{tabular}

a. Dependent Variable: TOTALLY

Sumber: Data primer diolah, 2019

Berdasarkan hasil perhitungan, diperoleh persamaan regresi linier berganda yang signifikan sebagai berikut :

$$
\mathrm{Y}=-29,018+1,110 \mathrm{X} 1+0,777 \mathrm{X} 2+\mathrm{e}
$$

Uji Statistik t

Uji t digunakan untuk mengetahui pengaruh variabel independen terhadap variabel dependen (Ghozali, 2011).

Tabel 6. Hasil Uji t

\begin{tabular}{lcc}
\hline \multicolumn{1}{c}{ Model Anova } & $\boldsymbol{t}_{\text {hitung }}$ & $\boldsymbol{t}_{\text {sig. }}$ \\
\hline Kepemimpinan Transformasional (X1) & 2,805 & 0,09 \\
Motivasi (X2) & 3,483 & 0,02 \\
\hline Sumber: Data primer diolah, 2019
\end{tabular}

Sumber: Data primer diolah, 2019

Besarnya nilai $t_{\text {hitung }}$ kepemimpinan transformasional 2,805 $>2,051$ sehingga dapat dikatakan bahwa hipotesis yang menyatakan kepemimpinan transformasional (X1) berpengaruh secara parsial terhadap kinerja karyawan (Y) di terima. Besarnya nilai $t_{\text {hitung }}$ motivasi 3,483 > 2,051 sehingga dapat dikatakan bahwa hipotesis yang menyatakan variabel motivasi (X2) berpengaruh secara parsial terhadap variabel kinerja karyawan (Y) bisa diterima. 
Uji Statistik F

Uji $F$ digunakan untuk menunjukkan pengaruh variabel independen yaitu kepemimpinan transformasi (X1) dan motivasi (X2) terhadap variabel dependen yaitu kinerja (Y) (Ghozali, 2011).

Tabel 7. Hasil Uji F

\begin{tabular}{lccc}
\hline \multicolumn{1}{c}{ Model } & df & F & Sig. \\
\hline Regression & 2 & 36,801 & 0,000 \\
Residual & 27 & & \\
Total & 29 & & \\
\hline
\end{tabular}

Sumber: Data primer diolah, 2019

Besarnya nilai $F_{\text {tabel }} 36,801>3,35$ sehingga dapat dikatakan bahwa hipotesis yang menyatakan kepemimpinan transformasional (X1) dan motivasi (X2) berpengaruh secara simultan terhadap kinerja karyawan (Y) bisa diterima.

Koefisien Determinasi $\left(R^{2}\right)$

Koefisien determinasi digunakan untuk menguji goodness-fit dari model regresi (Ghozali, 2011).

\section{Tabel 8. Hasil Koefisien Determinasi}

\begin{tabular}{lrrrr}
\hline & \multicolumn{3}{c}{ Adjusted $R$} \\
Model & $\mathrm{R}$ & $\mathrm{R}$ Square & Square & Std. Error of the Estimate \\
\hline 1 & $.724^{\mathrm{a}}$ & .524 & .489 & 5.908 \\
\hline
\end{tabular}

Sumber: Data primer diolah, 2019

Besarnya nilai koefisien determinasi (adjusted $R^{2}$ ) yang diperoleh yaitu sebesar 0,489. Hal ini berarti sebesar 48,9\% kinerja karyawan dipengaruhi oleh faktor kepemimpinan transformasional dan motivasi sedangkan sisanya yaitu sebesar $51,1 \%$ kinerja karyawan dipengaruhi oleh variabel-variabel lainnya yang tidak diteliti dalam penelitian ini.

\section{SIMPULAN}

Penelitian ini meberikan bukti empiris mengenai pengaruh kepemimpinan transformasional dan motivasi terhadap kinerja karyawan baik secara parsial maupun simultan. Variabel kepemimpinan transformasional berpengaruh secara parsial terhadap kinerja karyawan Credit Union (CU) Betang Asi Palangka Raya. Variabel motivasi berpengaruh secara parsial terhadap kinerja karyawan Credit Union (CU) Betang Asi Palangka Raya. Variabel kepemimpinan transformasional dan motivasi berpengaruh secara simultan terhadap kinerja karyawan Credit Union (CU) Betang Asi Palangka Raya. Berdasarkan hasil penelitian diatas, saran yang dapat diberikan adalah:

Pemimpin hendaknya dapat tetap menjaga hubungan yang baik terhadap karyawan di dalam bekerja, sehingga karyawan merasa nyaman di dalam bekerja. Pemimpin diharapkan agar lebih banyak menyediakan waktu secara personal terhadap karyawan. Penelitian selanjutnya agar memperbaiki keterbatasan yang ada dalam penelitian ini dan memperbanyak jumlah sampel dan cara pengambilan data untuk mendapatkan hasil yang 
menyeluruh. Penelitian selanjutnya agar dapat mengkaji variabel lain yang dapat mempengaruhi kinerja.

\section{REFERENSI}

Ghozali, Imam. (2011). Aplikasi Analisis Multivariate Dengan Program SPSS. Semarang: Badan Penerbit Universitas Diponegoro

Kasmir. (2014). Analisis Laporan Keuangan Edisi Satu.Cetakan Ketujuh. Jakarta. PT. Raja Grafindo Persada

Lupiyoadi, Rambat dan Ikhsan, Ridho Bramulya. 2015. Praktikum Metode Riset Bisnis, Jakarta: Salemba Empat

Northouse, P. G. (2013). Kepemimpinan. Jakarta Barat: PT. Indeks

Nurhadian, A. F. (2017). Pengaruh kepemimpinan transformasional dan motivasi kerja terhadap kinerja karyawan. Jurnal Ekonomi, Bisnis \& Entrepreneurship, 11(1), 5974.Panggabean, M. S. (2004). Manajemen Sumber Daya Manusia. Bogor Selatan: Ghalia Indonesia

Sedarmayanti, 2010, Sumber Daya Manusia dan Produktivitas Kerja , cetakan kedua, penerbit: Mandar Maju. Bandung

Tania, Y. (2017). Pengaruh Gaya Kepemimpinan Transformasional dan Motivasi Kerja terhadap Kinerja Karyawan pada PT. Premier Management Consulting. Agora, 5(1).Wibowo. (2014, April). Manajemen kinerja. Jakarta: PT Rajagrafindo Persada 